\title{
SYNTHESIS, CHARACTERIZATION AND CYTOTOXICITY OF CERTAIN PEG400 BASED BIODEGRADABLE ALIPHATIC COPOLYESTERS
}

\author{
B. Yamini ${ }^{1, *}$ and R. Nanthini ${ }^{2}$ \\ ${ }^{1}$ Department of Chemistry, Saveetha Engineering College, Chennai, Tamilnadu, India \\ ${ }^{2}$ Department of Chemistry, Pachaiyappa's College, Chennai-30, Tamilnadu, India \\ *E-mail: chemistryyamini@gmail.com
}

\begin{abstract}
Random aliphatic copolymers synthesized by direct melt polycondensation reaction between Polyethylene glycol dodecanediol succinate (PEDDSU) and Polyethylene glycol dodecanediol sebacate (PEDDSE). This reaction occurred with titanium tetra-isopropoxide Ti(ipo $)_{4}$ as a catalyst. The characterization studies were examined by IR Spectroscopy, Nuclear magnetic resonance (NMR), Thermal analysis (DSC), Wide angle x-ray diffraction (WAXD) and molecular weight determination by Gel permeation chromatography (GPC). The viscosity and solubility studies are also measured for the newly synthesized copolyesters. Inherent viscosities were studied using ubbelholde viscometer. The addition of methylene units in the di-acid results in a decrease of $\mathrm{T}_{\mathrm{m}}$ and $\mathrm{T}_{\mathrm{g}}$ from the DSC analysis of copolyesters. The studies on number average and weight average molecular weight of these copolyesters have confirmed their molecular weights. We have also studied the anticancer activity of these copolyesters which were tested against $V E R O$ and $M C F-7$ cell lines. The results of these studies conclude that both the obtained copolymers showed tremendous activity towards the anticarcinogenic property.

Keywords: aliphatic copolyester, polycondensation, differential scanning calorimetry, anticancer activity.

(c) RASĀYAN. All rights reserved
\end{abstract}

\section{INTRODUCTION}

Aliphatic polyesters made from bifunctional acids and diols are expected to be competitive biodegradable polymers because they are easily digested and degraded completely by microorganisms ${ }^{1}$. These copolyesters can easily enter the metabolic cycles of bio-organisms, readily susceptible to biological attack due to its non-toxicity ${ }^{2,3}$. These copolyesters exhibit good solubility in most of the common solvents, essentially required for its applications $s^{4,5}$. Previously with the absence of a catalyst, aliphatic polymers produced only low molecular weight polyesters derived from their respective diols and diacids. But with the presence of transesterification catalysts, high molecular weight polyesters are obtained with improved mechanical properties ${ }^{4}$. In general, high molecular weight polymers require a longer time to attain equilibrium ${ }^{6,7}$.

Polyethylene glycol (PEG) is one of the polymers that is been widely accepted by food and drug administration (FDA), as the most biocompatible polymers for internal consumption ${ }^{8,9}$. With PEG as a monomer, the properties like biocompatibility, hydrophilicity is improved and widely used as biomaterials ${ }^{10}$. Although the structure of PEG is very simple, its macromolecule causes cell fusion at very high concentration, also facilitates the movement of molecules across cell membranes. The hydroxyl groups available at both the ends provide chemically active sites to change the hydroxyls to other higher activity groups ${ }^{8}$.

Johnna S. Temenoff et $\mathrm{al}^{11}$ designed to prepare a unique polymer oligo (polyethylene glycol fumarate) (OPF) to obtain hydrogels which possess swelling and mechanical property. Feixiong et $a l^{6}$ synthesized a series of monooleate poly (ethylene glycol) with one-ended active carboxylic terminal and succinic anhydride to complete the grafting of hydrophobic end-group oleate. Veeran Gowda Kaddajji et al ${ }^{12}$ prepared water-soluble polymers for biomedical and pharmaceutical applications. Mayson H. Ziboon et 
a ${ }^{13}$ synthesized poly (ethylene glycol)-sebacic acid with sebacic anhydride to produce biocompatible and nontoxic polymers.

In this proposal,the synthesis of aliphatic polyesters from 1, 12 - dodecanediol, PEG 400 and succinic / sebacic acid by melt polycondensation technique is described with respect to Titanium (IV) isopropoxide as the catalyst. The synthesized copolyesters are characterized by solubility, inherent viscosity, spectral studies, molecular weight determination and thermal analysis. The anticancer activities of these copolyesters and their cell viabilities were tested and compared against normal and adenocarcinoma cell lines.

\section{Material and Methods}

\section{EXPERIMENTAL}

PEG400, succinic acid, sebacic acid and 1, 12 - dodecanediol were purchased from Merck and used as such. Titanium (1V) isopropoxide purchased from spectrochem were used as a catalyst. Other chemicals and solvents were utilized directly.

\section{Preparation of PEDDSU and PEDDSE copolymers}

The synthesis of aliphatic copolyesters is carried out by two-step melt polycondensation method. The reaction proceeds with a three-necked round bottom flask furnished with dry nitrogen gas, an inlet tube, guard tube and magnetic stirrer purged with a mixture of PEG400, sebacic acid/succinic acid and 1, 12 dodecanediol with a small amount of titanium (IV) isopropoxide as a catalyst. The reaction mixture is heated up to $160^{\circ} \mathrm{C}$ for 2 hours in the presence of nitrogen gas to remove the excess water. To attain postpolymerization, the temperature in the reaction flask is increased further to $200^{\circ} \mathrm{C}$ for 1 hour under reduced pressure to remove the traces of water.The obtained copolyester (polyethylene glycol-cododecanediolsebacate) and (polyethylene glycol-co-dodecanediol succinate) were purified by mixing with the smallest quantity of acetone; the mixture is vigorously stirred for 20 minutes with ice-cold methanol. The obtained slurry is washed with methanol, again and again, filtered and dried at room temperature under reduced pressure $(760 \mathrm{~mm} / \mathrm{Hg})^{4}$.

$$
\begin{aligned}
& \text { PEDDSU } \\
& \mathrm{nOH}-\left(\mathrm{CH}_{2}\right)_{n}-\mathrm{OH}+\mathrm{HOOC}-\left(\mathrm{CH}_{2}\right)_{2}-\mathrm{COOH}+\mathrm{OH}-\left(\mathrm{CH}_{2}\right)_{12}-\mathrm{OH} \\
& \downarrow \begin{array}{c}
200^{\circ} \mathrm{C}, \mathrm{Ti}(\mathrm{IPO})_{4} \\
-\mathrm{H}_{2} \mathrm{O}
\end{array} \\
& n\left[\mathrm{OH}-\left(\mathrm{CH}_{2}\right)_{n}-\mathrm{OOC}-\left(\mathrm{CH}_{2}\right)_{2}-\mathrm{COO}-\left(\mathrm{CH}_{2}\right)_{12}-\mathrm{O}\right]_{n} \\
& \text { PEDDSE } \\
& \mathrm{nOH}-\left(\mathrm{CH}_{2}\right)_{n}-\mathrm{OH}+\mathrm{HOOC}-\left(\mathrm{CH}_{2}\right)_{6}-\mathrm{COOH}+\mathrm{OH}-\left(\mathrm{CH}_{2}\right)_{12}-\mathrm{OH} \\
& \downarrow 200^{\circ} \mathrm{C}, \mathrm{Ti}(\mathrm{IPO})_{4} \\
& n\left[\mathrm{OH}-\left(\mathrm{CH}_{2}\right)_{n}-\mathrm{OOC}-\left(\mathrm{CH}_{2}\right)_{6}-\mathrm{COO}-\left(\mathrm{CH}_{2}\right)_{12}-\mathrm{O}\right]_{n}
\end{aligned}
$$

\section{Instruments}

The nuclear magnetic $\left({ }^{1} \mathrm{H}\right.$ NMR) spectra were determined by Bruker AVIII $500 \mathrm{MHz}$ with deuterated $\mathrm{CDCl}_{3}$ as a solvent with TMS as the standard. Fourier transforms vibrational spectra of the copolyesters were recorded using potassium bromide pellets on a Shimadzu make over the range of $400-4000 \mathrm{~cm}^{-1}$. In the Perkin Elmer DSC- 2 instrument, the values are scanned under a dry nitrogen atmosphere. The polymeric samples around $10 \mathrm{mg}$ were weighed approximately and kept in a closed aluminium pan, scanned over a range of $-50{ }^{\circ} \mathrm{C}$ to $300{ }^{\circ} \mathrm{C}$ and heated at a rate of $10^{\circ} \mathrm{C} / \mathrm{min}$. Thermal stability was determined by thermogravimetric analysis (TGA, Perkin Elmer TGS - 2 instruments) over the range of ambient to $800^{\circ} \mathrm{C}$ at a heating rate of 10 degree celsius per minute. The X-ray powder diffraction (WAXD) studies were conducted with a help of GE X-RAY 3003 diffractometer employing $\mathrm{Cu} \mathrm{K}_{<}$ filtered radiation to inspect the amorphous / crystallinity of the polymer samples. The molecular weights 
were determined on a waters GPC system (water 515 pumps) with RI detector 2414 at a temperature of 35 ${ }^{\circ} \mathrm{C}$ in the presence of THF as a solvent.

MTT Assay - Anticancer activity for Adenocarcinoma cell line

The antitumor activity of the normal and MCF-7 cell lines was resolved by the MTT assay (told by Mossman et al., in the year 1983) ${ }^{14}$. The cells were seeded in 96-well plates (density: 10000 cells/well), incubated at $37^{\circ} \mathrm{C}$ with $5 \% \mathrm{CO}_{2}$ incubator. After confluence, the samples were expelled from the well and cleansed with phosphate-buffered saline ( $\mathrm{pH} 7.4)$ solution. Then in a $100 \mu \mathrm{l} /$ well $(5 \mathrm{mg} / \mathrm{ml}) 0.5 \%$ of $3-(4$, 5-dimethyl-2-thiazolyl)-2, 5-diphenyl-tetrazolium bromide (MTT) were poured and incubated for 4 hours. The absorbance was measured with UV-Spectrophotometer at $540 \mathrm{~nm}$ using DMSO as blank. The results were calculated for both VERO and MCF- 7 cell lines. The viability percentage of the cells were calculated by using:

\section{Cell viability $(\%)=$ A540 of viable cells / A540 of control cells $\times 100$}

\section{Solubility and Viscosity Measurements}

\section{RESULTS AND DISCUSSION}

The solubilities of the copolymers are displayed in the Table-1. The obtained copolyesters are insoluble in water, methanol, hexane and diethyl ether ${ }^{15}$. Inherent viscosities of the copolyesters were confirmed using chloroform as solvent at room temperature with the help of ubbelhode viscometer. The rate of flow time with respect to solvent and copolyester was found at a concentration of $1 \mathrm{mg} / \mathrm{ml}^{16}$. The inherent viscosity of the copolyester PEDDSU is $0.3498 \mathrm{dL} / \mathrm{g}$ and PEDDSE is $0.3765 \mathrm{dl} / \mathrm{g}$ shown in the Table- 1 .

Table-1: Inherent viscosity and solubility of copolyester PEDDSU and PEDDSE

\begin{tabular}{c|c|c|c|c|c}
\hline S. No. & Polymer & $\begin{array}{c}\text { Inherent Viscosity } \\
\mathrm{d} / \mathrm{g}\end{array}$ & Freely Soluble & $\begin{array}{c}\text { Sparingly } \\
\text { Soluble }\end{array}$ & Insoluble \\
\hline 1 & PEDDSU & 0.3498 & Chloroform,CCl & Acetone & Water, Methanol \\
\hline 2 & PEDDSE & 0.3765 & DCM \& THF & DMF & $\begin{array}{c}\text { Hexane, } \\
\text { diethyl ether }\end{array}$ \\
\hline
\end{tabular}

\section{Spectral Analysis}

The FT-IR vibrational spectra were recorded in the transmission mode for the synthesized copolymers, shown in Fig.-1.

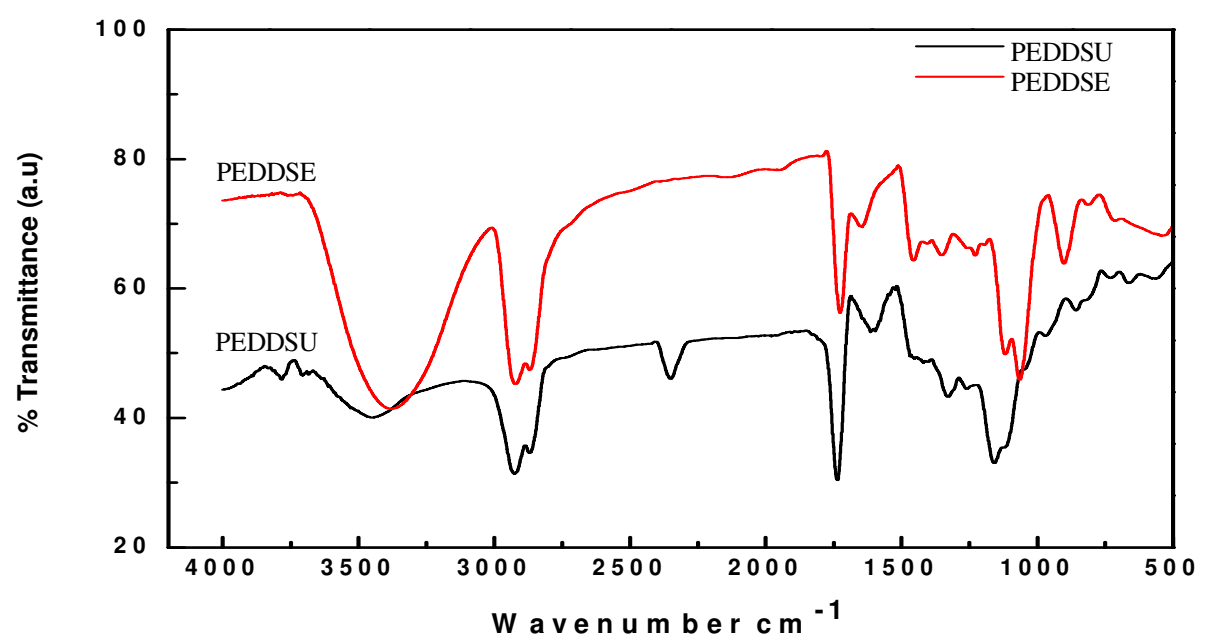

Fig.-1: FTIR Spectrum of PEDDSU and PEDDSE 
RASĀYAN J. Chem.

Vol. 11 | No. 2 |440 - 451 | April - June | 2018

The characteristic absorption bands for the synthesized copolymers are shown in Table- 2 .

Table-2: Absorption Range Frequency and its Assignment

\begin{tabular}{c|c|l}
\hline \multicolumn{2}{c|}{ Absorption frequency, $\mathrm{cm}^{-1}$} & \multicolumn{1}{c}{ Assignment } \\
\hline PEDDSU & PEDDSE & C=O stretching of ester group \\
\hline 1739 & 1727 & C-O stretching of ester group \\
\hline 1153 & 1226 & Aliphatic C-C stretching \\
\hline 1460 & 1469 & Aliphatic C-H stretching \\
\hline 2926 & 2919 & Broad band assigned to hydroxyl group \\
\hline
\end{tabular}

\section{${ }^{1}$ H NMR Spectral Data of Copolyesters, PEDDSU, and PEDDSE}

In the Proton NMR spectrum of PEDDSU, the multiplets split at $4.06 \mathrm{ppm}$ to $4.09 \mathrm{ppm}$ and $4.24 \mathrm{ppm}$ correspond to the methylene protons attached to hydroxyl group ${ }^{17,18}$. The signals at $3.63 \mathrm{ppm}$ with four proton integrals were allocated to methylene protons attached to the carbonyl carbon of ester oxygen atom. In addition, the peaks obtained at $2.62 \mathrm{ppm}$ to $2.66 \mathrm{ppm}$ and $2.29 \mathrm{ppm}$ to $2.34 \mathrm{ppm}$ corresponds to the methylene protons of succinic and sebacic acid moiety. The other two multiplets observed at $1.26 \mathrm{ppm}$ to $1.30 \mathrm{ppm}$ and $1.60 \mathrm{ppm}$ to $1.61 \mathrm{ppm}$ was subjected to dodecanediol of the synthesized polymer ${ }^{19,20}$. The copolyesters prepared from melt polycondensation have a random distribution of the monomers during the transesterification process ${ }^{21,22}$. The spectra of polyesters are shown in Fig. 2 and 3 and the characteristic peak values of PEDDSU and PEDDSE are shown in Table-3.

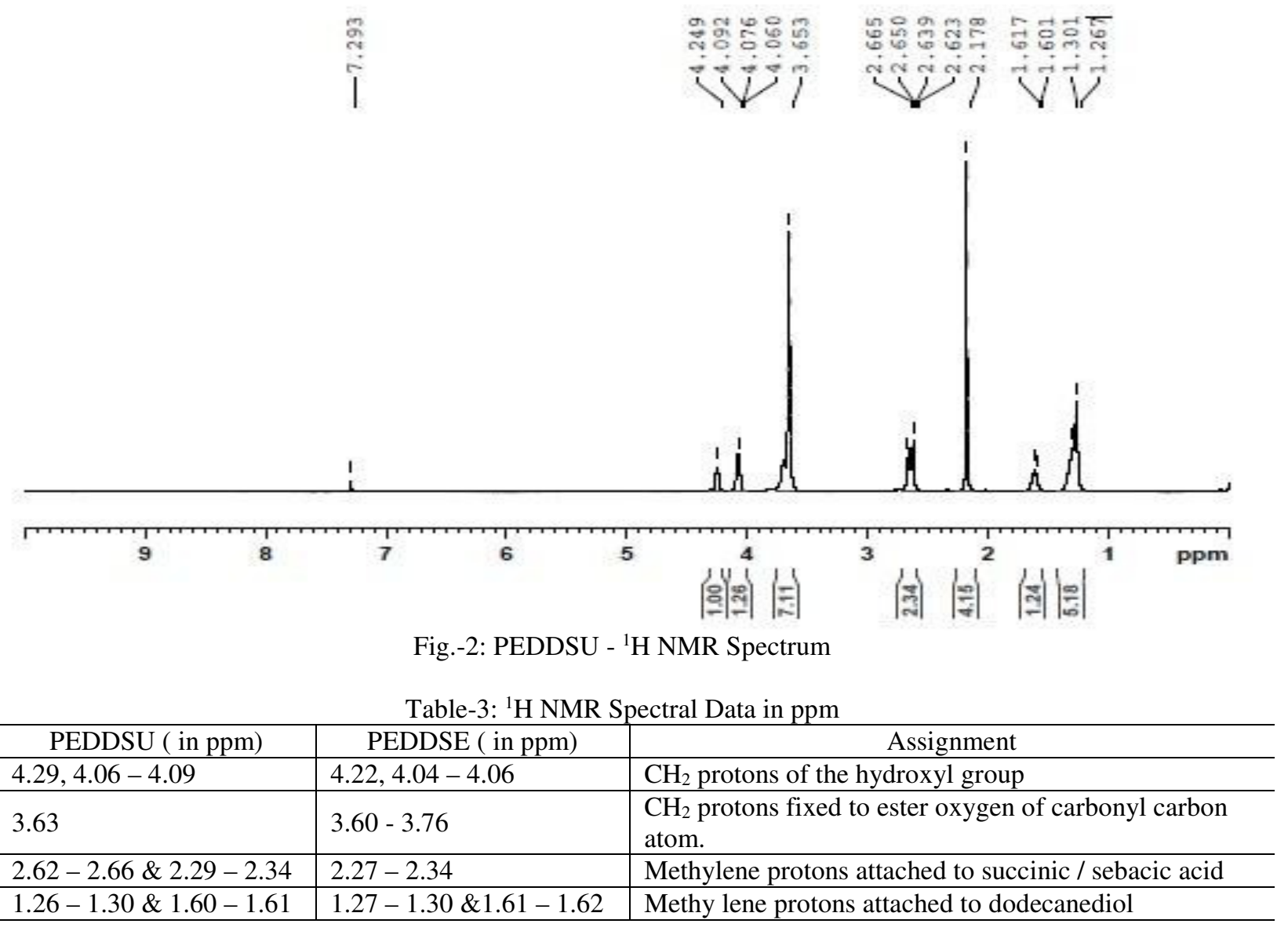




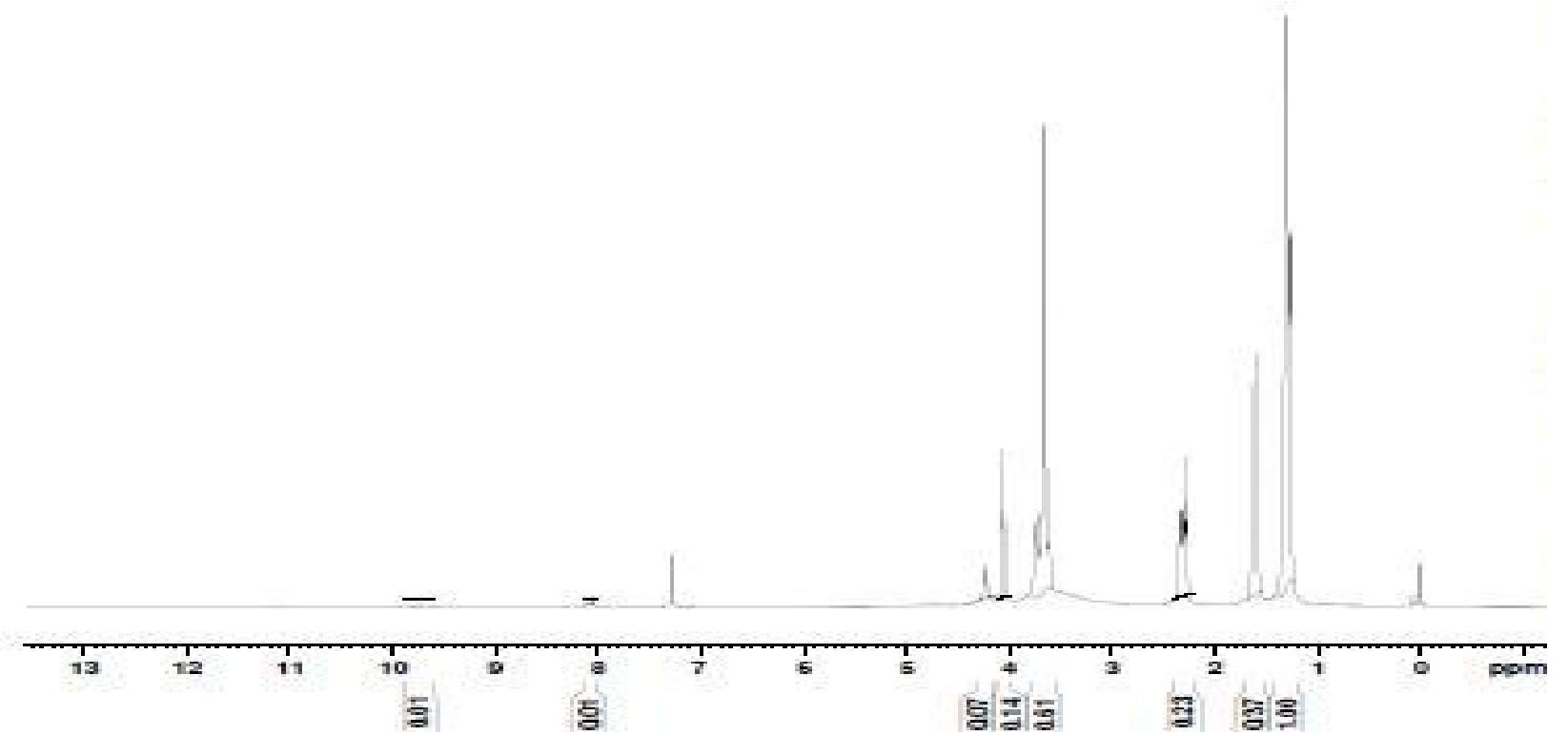

Fig.-3: PEDDSE $-{ }^{1} \mathrm{H}$ NMR Spectrum

The ${ }^{13} \mathrm{C}$ NMR spectrum was recorded to determine the skeletal structure of the copolymers with respect to deuterated chloroform as solvent. ${ }^{23,24}$. The peaks obtained in the range of $172.3 \mathrm{ppm}$ to $172.4 \mathrm{ppm}$ and $173.9 \mathrm{ppm}$ to $177.6 \mathrm{ppm}$ confirms the presence of ester carbonyl carbon ${ }^{25}$. The other signals noticed from $69.0 \mathrm{ppm}$ to $63.8 \mathrm{ppm}$ and $70.9 \mathrm{ppm}$ to $64.9 \mathrm{ppm}$ was assigned to methylene carbons attached to hydroxy and ester groups. ${ }^{13} \mathrm{C}$ peaks detected from $25.8 \mathrm{ppm}$ to $32.7 \mathrm{ppm}$ were assigned to the rest of the methylene carbons in the acid and dodecane part of the compound. The signals viewed at $24.6 \mathrm{ppm}$ to $29.4 \mathrm{ppm}$ were due to the carbon atoms of succinic subunit ${ }^{26}$. All the above characteristic peaks are shown in the Fig. -4 and 5.

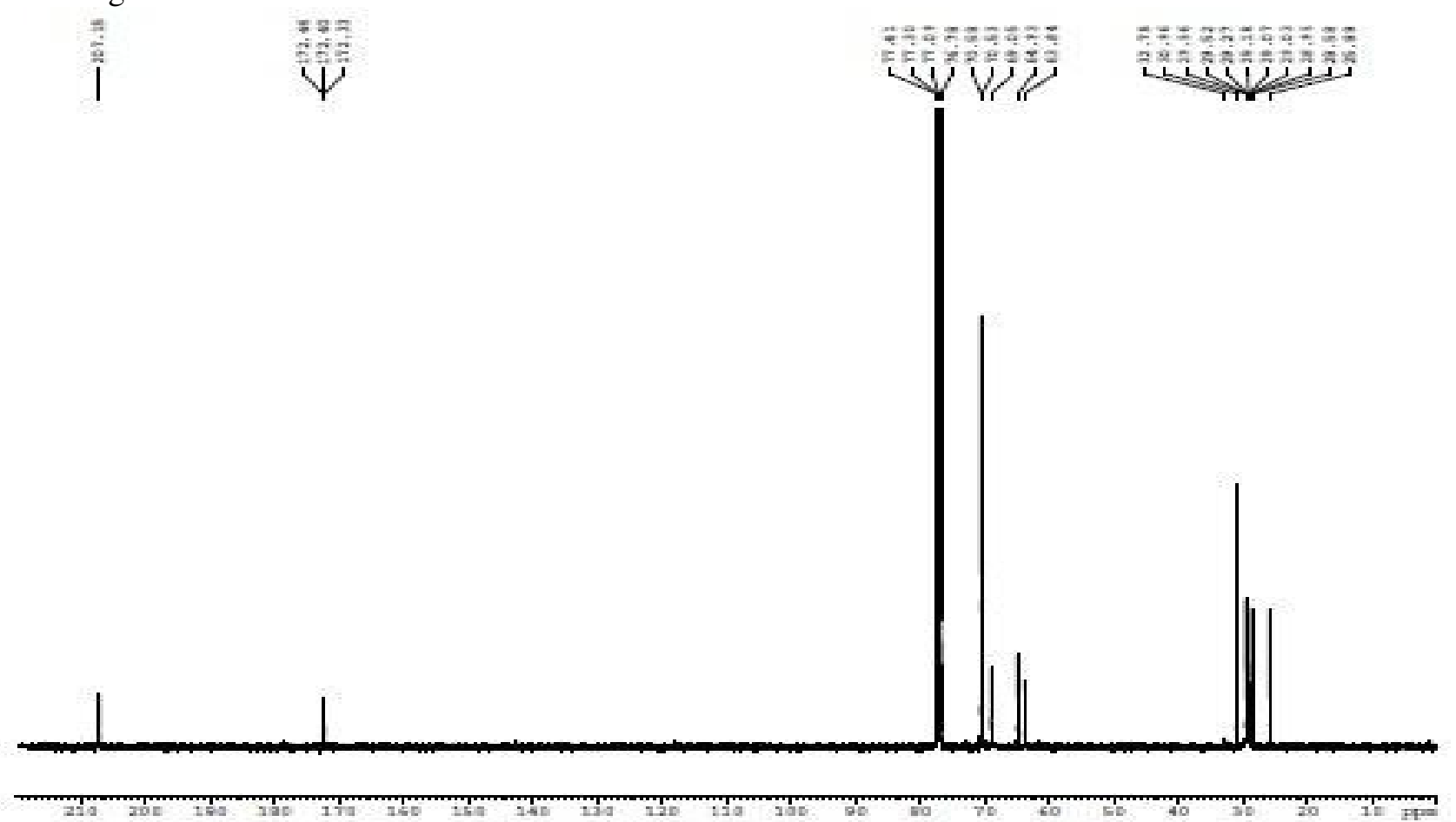

Fig.-4: ${ }^{13} \mathrm{C}$ NMR Spectrum of PEDDSU 


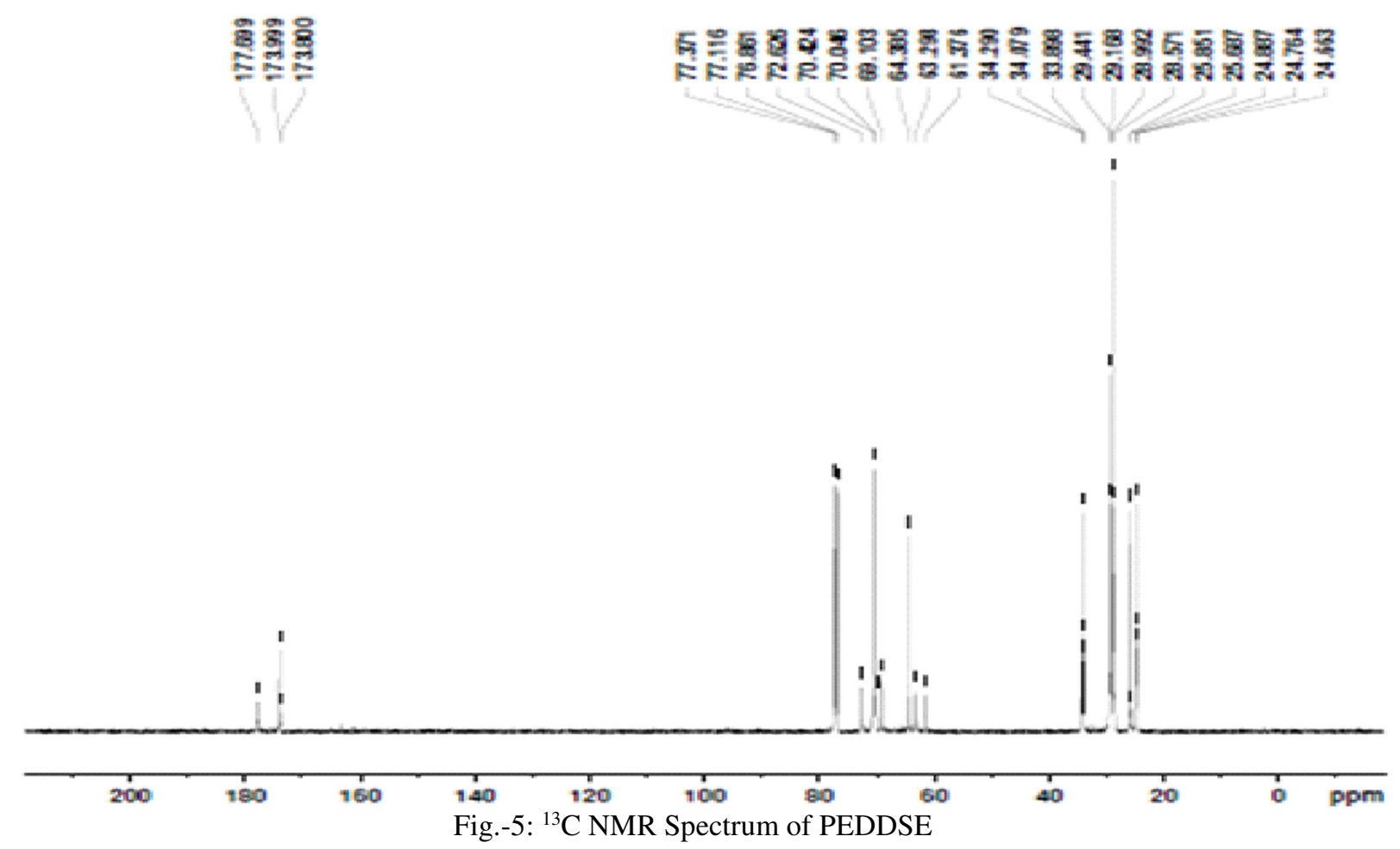

From the confirmations of IR and NMR, we infer that the structural units in the copolymers are disbursed randomly.

$$
\begin{aligned}
& n\left[\mathrm{OH}-\left(\mathrm{CH}_{2}\right)_{n}-\mathrm{OOC}-\left(\mathrm{CH}_{2}\right)_{2}-\mathrm{COO}-\left(\mathrm{CH}_{2}\right)_{12}-\mathrm{O}\right]_{n}(\mathrm{PEDDSU}) \\
& n\left[\mathrm{OH}-\left(\mathrm{CH}_{2}\right)_{n}-\mathrm{OOC}-\left(\mathrm{CH}_{2}\right)_{6}-\mathrm{COO}-\left(\mathrm{CH}_{2}\right)_{12}-\mathrm{O}\right]_{n}(\mathrm{PEDDSE})
\end{aligned}
$$

\section{Thermal Analysis}

The thermal analysis is conducted for the synthesized copolymer to find their practical applications. The DSC thermograms of PEDDSU and PEDDSE are shown in Fig.- $6 \&$ 7. The variation in the thermal behavior of the synthesized polymers depends on the increase in a number of methylene groups in the repeating unit. The glass transition temperature always determines the chain flexibility of the obtained polymers. From Fig.-6 and 7, it is observed that the $\mathrm{T}_{\mathrm{g}}$ and $\mathrm{T}_{\mathrm{m}}$ were found to be at $-15.60^{\circ} \mathrm{C}$ and $145.76^{\circ} \mathrm{C}$. Whereas, for PEDDSE the glass transition and melting temperatures were found to be at $75.0^{\circ} \mathrm{C}$ and $69.69^{\circ} \mathrm{C}$. It was found that the glass transition and melting temperatures decrease with increasing number of methylene units. The lower the $\mathrm{Tg}$, the more flexible are the polymer chains ${ }^{27,28}$. The $T_{g}$ and $T_{m}$ values suggest that both the copolyesters can be used for drug delivery applications, which is partially matched with the temperature of human body ${ }^{15}$.

Fig.-8 and 9 show the TGA thermogram of PEDDSU and PEDDSE copolyesters. It can be seen from the graph that the decomposition temperatures $\left(\mathrm{T}_{\mathrm{d}}\right)$ of the copolymers were observed at $358.70^{\circ} \mathrm{C}$ and $401.16^{\circ} \mathrm{C}$ for PEDDSU and PEDDSE. The decomposition temperature of sebacate copolymer is greater than succinate copolymer due to increase in chain length. A sharp bend noticed at $358.70^{\circ} \mathrm{C}$ and $401.16^{\circ}$ $\mathrm{C}$ confirm its crystanallity. This result is also supported by wide-angle X-ray diffraction spectrum $(\mathrm{WAXD})^{4}$.

\section{X-ray Diffraction Analysis}

The X-ray diffraction study is an effective tool to investigate the structure and crystanallity of the polymers. It is been performed for both the polymers PEDDSU and PEDDSE shown in Fig. 10 \& 11 respectively. The figure below shows a broad reflection peak at 2 theta $=21.54^{\circ}$ and $21.4^{\circ}$ which 
RASĀYAN J. Chem.

Vol. 11 | No. 2 | 440 - 451 | April - June | 2018

determines the crystalline nature of the polymer .whereas the peaks pertaining at $24.81^{\circ}, 41.55^{\circ}, 43.71^{\circ}$, $23.79^{\circ}$ and $40.43^{\circ}$ indicates the formation of crystalline nature ${ }^{29}$.

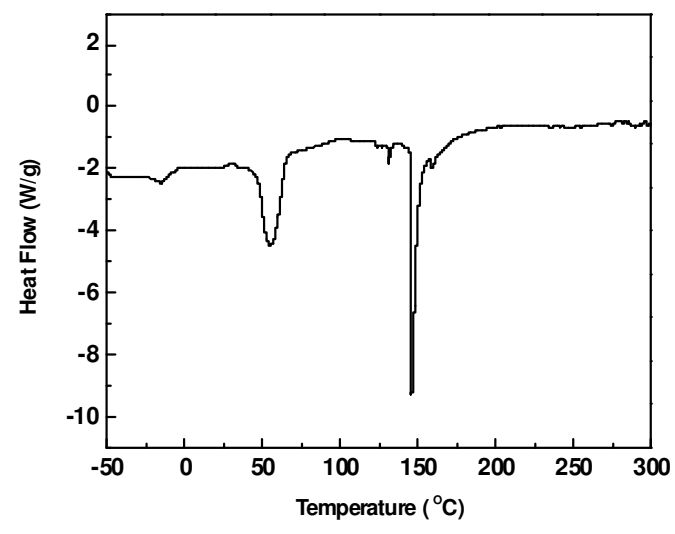

Fig.-6: DSC Spectrum of PEDDSU

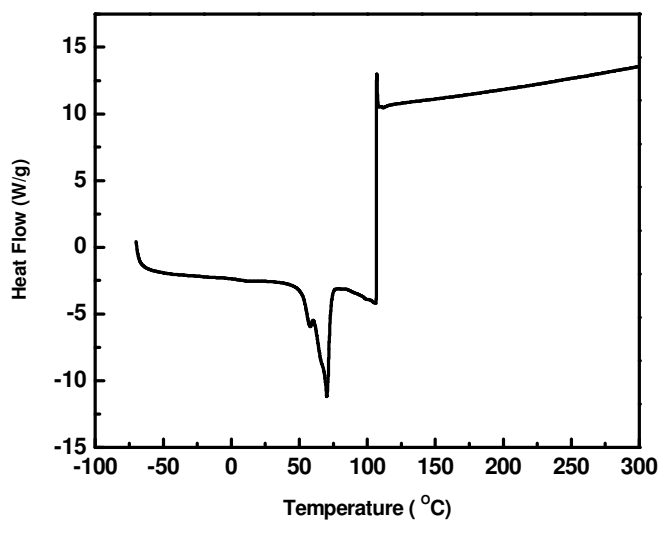

Fig.-7: DSC Spectrum of PEDDSE

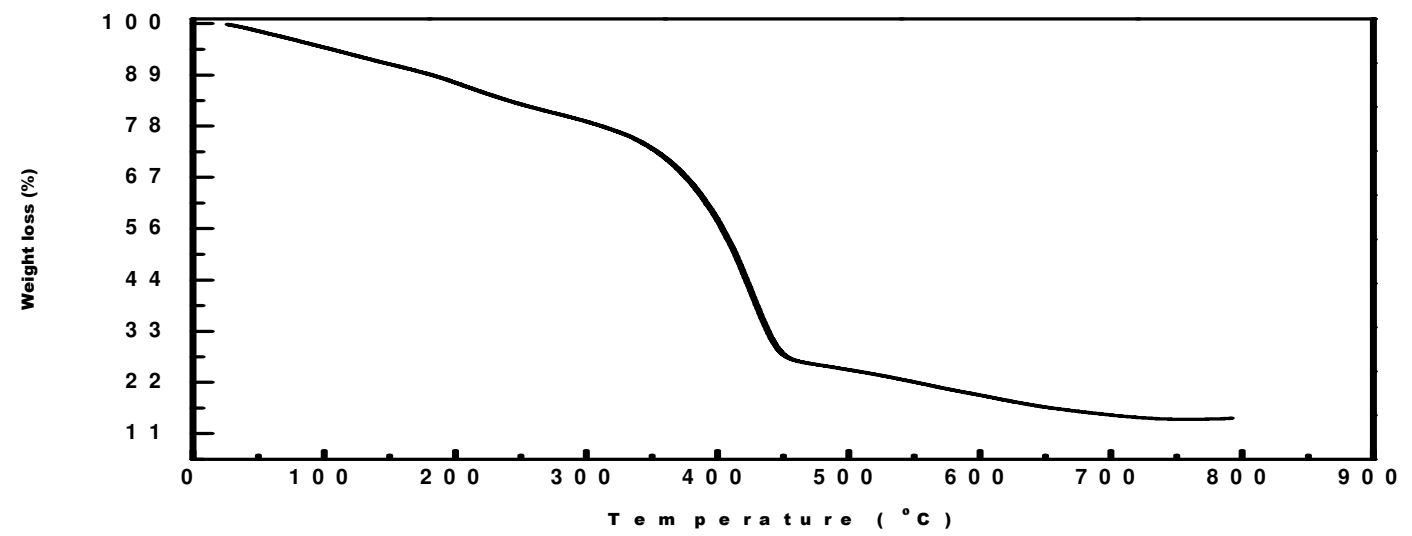

Fig.-8: TGA Spectrum of PEDDSU

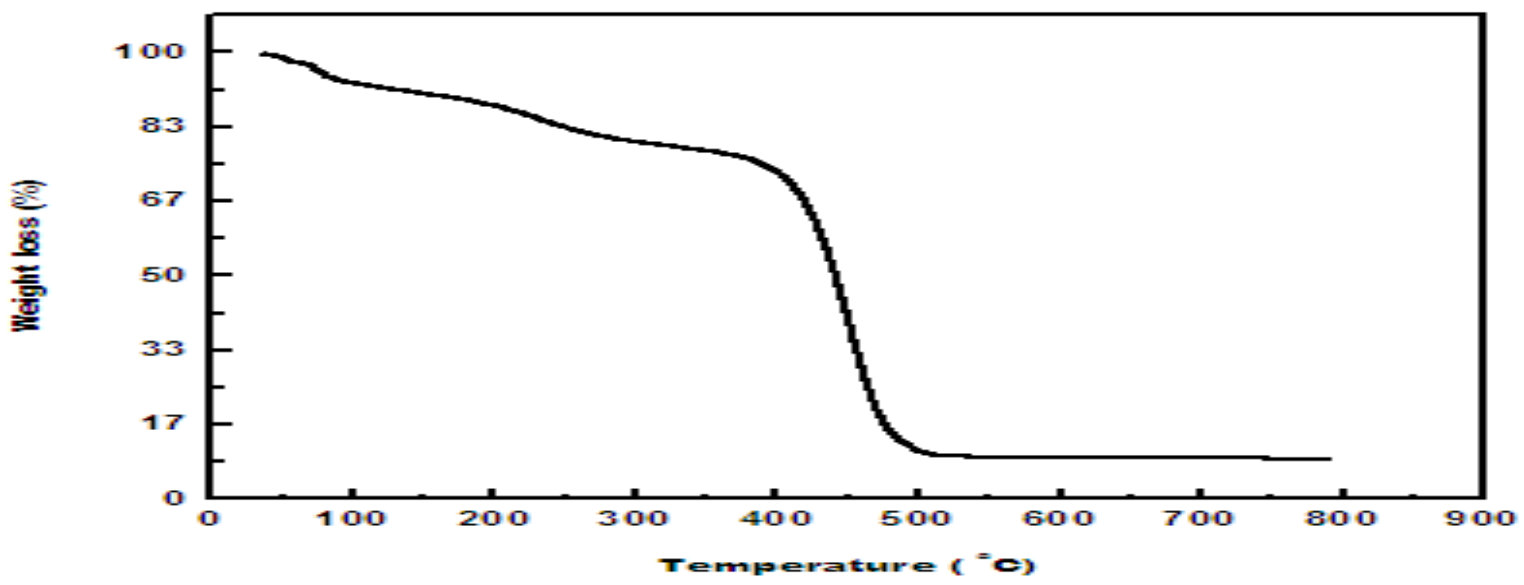

Fig.-9: TGA Spectrum of PEDDSE

The increase in the length of flexible segments is indicated by the crystalline nature of the polymeric samples, which in turn increases the intensity of the diffraction peaks ${ }^{30,31}$. From the values of $x$-ray diffraction measurement, it is perceived that the sebacate polymer is crystalline than the succinate polymer. 


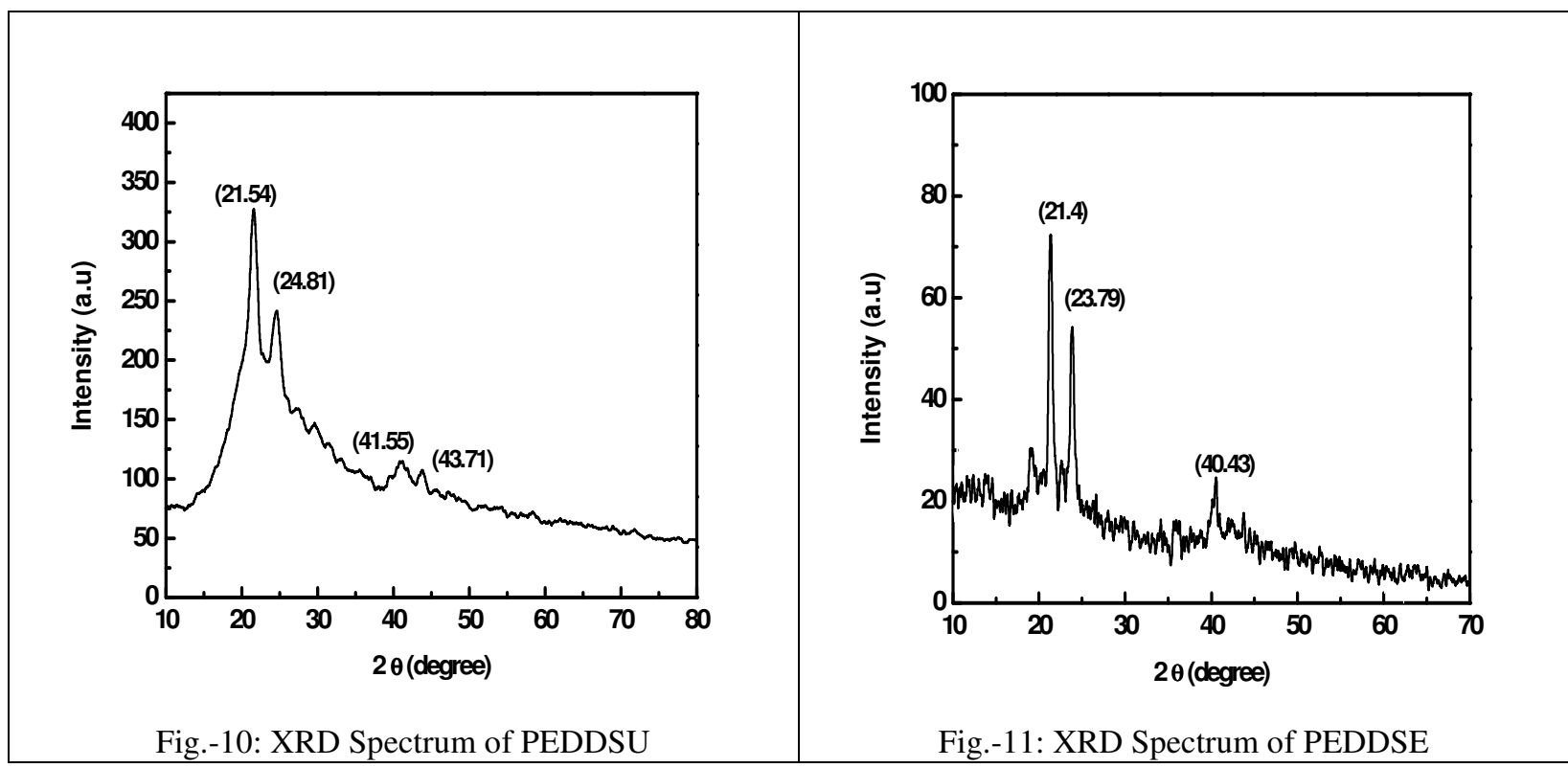

\section{GPC Analysis}

The relative molecular mass of the synthesized copolymers is conceived in Table-4. This technique determines the number-average and weight-average molecular weight of PEDDSU and PEDDSE. Reports reveal that this technique confirms the nature of copolyesters expected either in oligomeric or polymeric form $^{32}$. The polydispersity index $\left(M_{w} / M_{n}\right)$ and $\mathrm{M}_{\mathrm{w}}$ of succinate copolyester are higher than sebacate copolyester conclude that the polymers were distributed in a random manner. And the lower molecular weight of the polymer is more suitable for biological application ${ }^{15}$.

Table-4: Molecular Weight for the Copolyesters PEDDSU and PEDDSE

\begin{tabular}{c|c|c|c|c|c}
\hline S. No. & Polymer & $\mathrm{M}_{\mathrm{w}}$ & $\mathrm{M}_{\mathrm{n}}$ & $\mathrm{DP}$ & PDI \\
\hline 1 & PEDDSU & 4590 & 3841 & 11.9 & 1.19 \\
\hline 2 & PEDDSE & 4215 & 3850 & 10.17 & 1.12 \\
\hline
\end{tabular}

\section{Antitumor Efficacy Studies \\ MTT Assay}

The anticancer evaluation and its absorbance were identified by UV-spectrophotometer for the viable cells. The $\%$ cell viability and its $\mathrm{IC}_{50}$ values were determined for both $V E R O$ and $M C F-7$ cells which are displayed in Tables $-5,6$ and Tables $-7,8$. By graphical determination, 50\% inhibition of viability (IC ${ }_{50}$ ) was calculated for both the copolyesters PEDDSU and PEDDSE which are shown from Fig.-12 to Fig.19.

Table-5: Cytotoxic Values of Synthesized Compounds against VERO Cell Line in PEDDSU

\begin{tabular}{c|c}
\hline Concentration Compound $(\mu \mathrm{g} / \mathrm{mL})$ & Cell Viability $(\%)$ \\
\hline 1000 & 1.5 \\
\hline 500 & 18.1 \\
\hline 250 & 36.2 \\
\hline 125 & 51.1 \\
\hline 62.5 & 66.9 \\
\hline 31.2 & 100 \\
\hline Control cells & $56.25(\mu \mathrm{g} / \mathrm{mL})$ \\
\hline IC 50 value &
\end{tabular}


RASĀYAN J. Chem.

Vol. 11 | No. 2 |440 - 451 | April - June | 2018
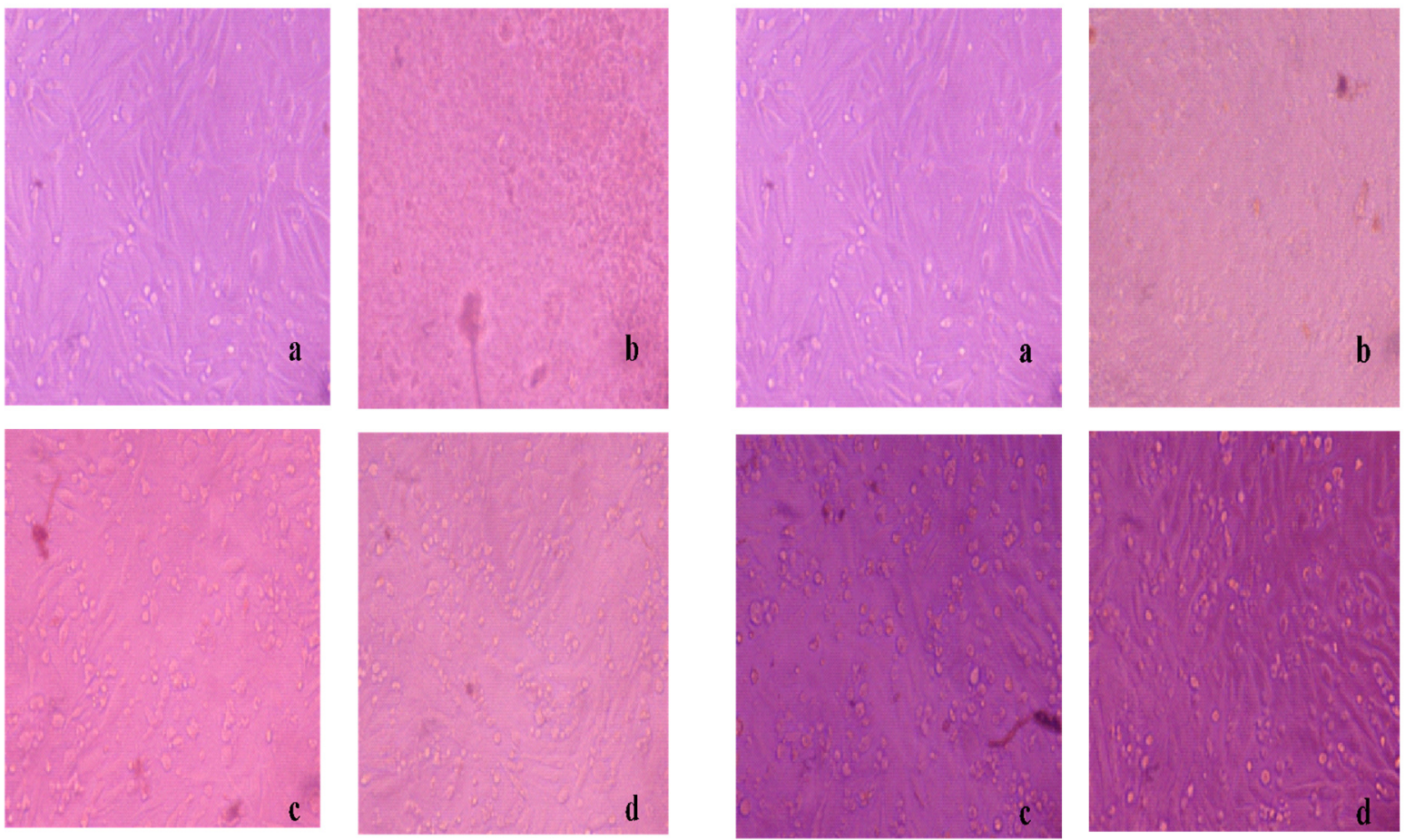

Fig. 12(a-d): Cytoxicity effect of Compound PEDDSU on VERO cell line a) Control; b) $1000 \mu \mathrm{g} / \mathrm{mL}$; c) $62.5 \mu \mathrm{g} / \mathrm{mL}$; d) $31.2 \mu \mathrm{g} / \mathrm{mL}$

Fig. 13(a-d): Cytoxicity effect of Compound PEDDSE on VERO cell line a) Control; b) $1000 \mu \mathrm{g} / \mathrm{mL}$; c) $62.5 \mu \mathrm{g} / \mathrm{mL}$; d) $31.2 \mu \mathrm{g} / \mathrm{mL}$

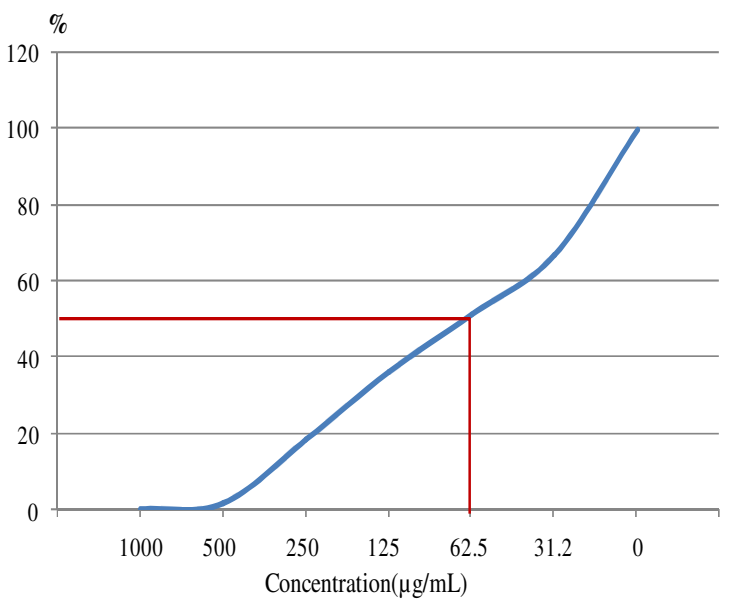

Fig. 14: Cell Viability of PEDDSU (VERO)

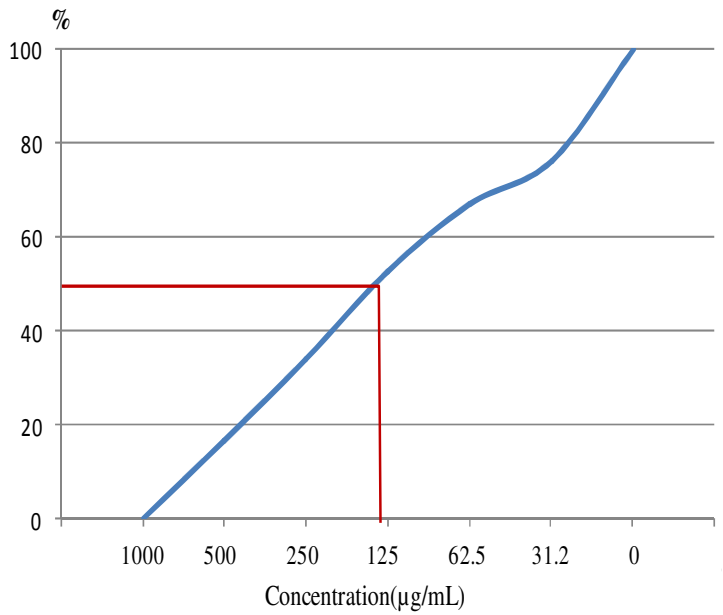

Fig. 15: Cell Viability of PEDDSE (VERO)

Table-6: Cytotoxic Values of Synthesized Compounds against VERO Cell Line in PEDDSE

\begin{tabular}{c|c}
\hline Concentration $(\mu \mathrm{g} / \mathrm{ml})$ & Cell Viability $(\%)$ \\
\hline 1000 & 0 \\
\hline 500 & 16.5 \\
\hline 250 & 33.8 \\
\hline 125 & 52.7 \\
\hline 62.5 & 66.9 \\
\hline 31.2 & 76.3 \\
\hline Control cells & 100 \\
\hline IC 50 value & $122.5(\mu \mathrm{g} / \mathrm{mL})$ \\
\hline
\end{tabular}


RASĀYAN J. Chem.

Vol. 11 | No. 2 | 440 - 451 | April - June | 2018

The PEDDSU and PEDDSE copolymers exhibited $\mathrm{IC}_{50}$ value (VERO Cell) at $56.25 \mu \mathrm{g} / \mathrm{ml}$ and 122.5 $\mu \mathrm{g} / \mathrm{ml}$. but in the case of adenocarcinoma cells $(M C F-7)$, the $\mathrm{IC}_{50}$ values were found to be $31.08 \mu \mathrm{g} / \mathrm{ml}$ and $29.77 \mu \mathrm{g} / \mathrm{ml}$. From the results of $V E R O$ cell lines it is inferred that PEDDSE is more cytotoxic than PEDDSU due to higher $\mathrm{IC}_{50}$ values. But from the results of $M C F-7$ cells, sebacate copolymer showed more anticancerous property than succinate copolymer due to lower $\left(\mathrm{IC}_{50}\right)$ values ${ }^{33}$. The maximum cancerous cell death occurred in sebacate when compared with succinate. Therefore from these results we conclude that PEDDSE is antiproliferative than PEDDSU ${ }^{34,35}$.

Table-7: Cytotoxicity of Synthesized Compounds against MCF-7 Cell Line in PEDDSU

\begin{tabular}{c|c}
\hline Concentration Compound $(\mu \mathrm{g} / \mathrm{mL})$ & Cell Viability $(\%)$ \\
\hline 1000 & 19.06 \\
\hline 500 & 22.95 \\
\hline 250 & 33.85 \\
\hline 125 & 41.43 \\
\hline 62.5 & 47.85 \\
\hline 31.2 & 55.25 \\
\hline 15.6 & 60.70 \\
\hline 7.8 & 69.45 \\
\hline Cell control & 100 \\
\hline IC 50 value & $31.08(\mu \mathrm{g} / \mathrm{mL})$ \\
\hline
\end{tabular}

Table-8: Cytotoxicity of Synthesized Compounds against MCF-7 Cell Line in PEDDSE

\begin{tabular}{c|c}
\hline Concentration $(\mu \mathrm{g} / \mathrm{ml})$ & Cell Viability $(\%)$ \\
\hline 1000 & 15.38 \\
\hline 500 & 23.80 \\
\hline 250 & 32.05 \\
\hline 125 & 36.85 \\
\hline 62.5 & 42.99 \\
\hline 31.2 & 52.39 \\
\hline 15.6 & 57.96 \\
\hline 7.8 & 62.76 \\
\hline Cell control & 100 \\
\hline IC 50 value & $29.77(\mu \mathrm{g} / \mathrm{mL})$ \\
\hline
\end{tabular}
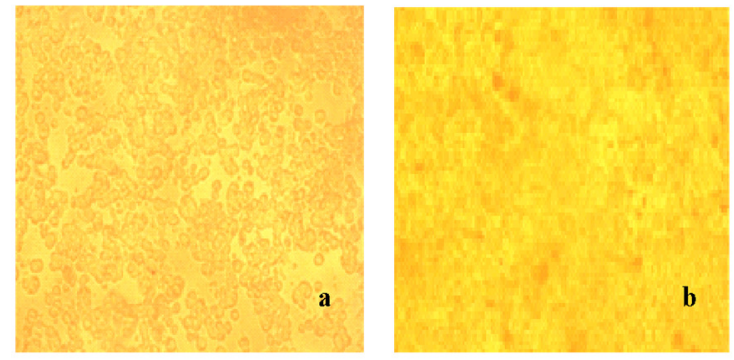

c

\section{d}

Fig. 16(a-d): Cytotoxicity effect of Compound PEDDSU on MCF-7 cell line: a) Control ; b. $1000 \mu \mathrm{g} / \mathrm{mL}$; c. $15.62 \mu \mathrm{g} / \mathrm{mL}$; d. $7.8 \mu \mathrm{g} / \mathrm{mL}$
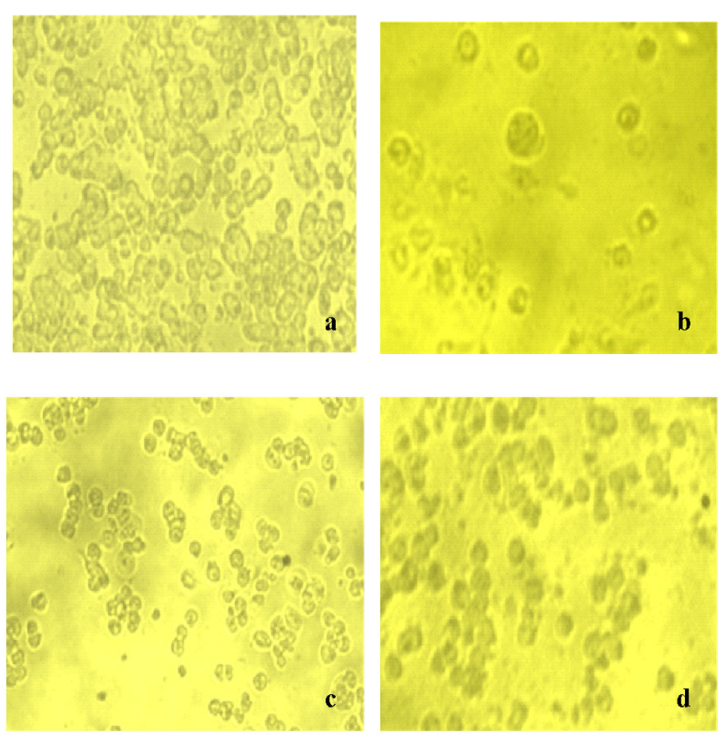

Fig. 17(a-d): Cytotoxicity effect of Compound PEDDSE on MCF-7 cell line: a) Control ; b. $1000 \mu \mathrm{g} / \mathrm{mL}$; c. $15.62 \mu \mathrm{g} / \mathrm{mL}$; d. $7.8 \mu \mathrm{g} / \mathrm{mL}$ 
$(\%)$

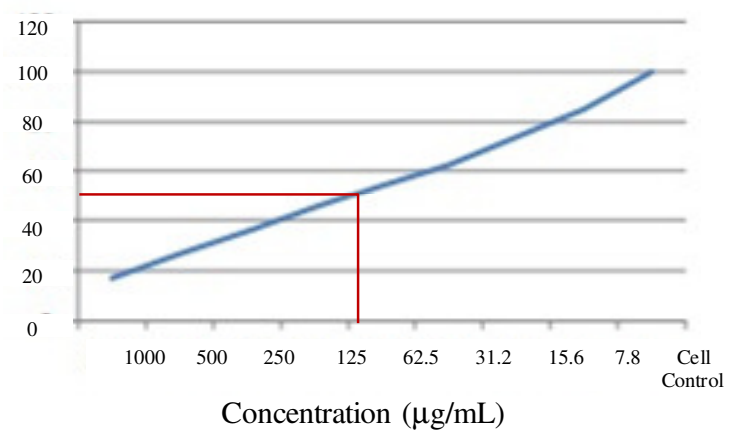

Fig. 18: Cell Viability of PEDDSU

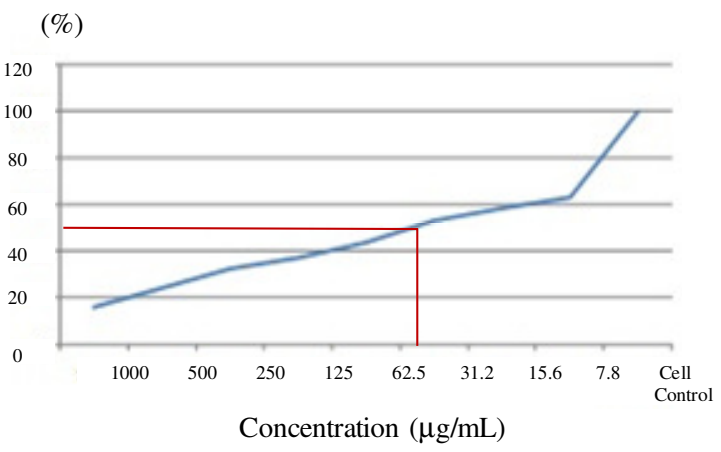

Fig. 19: Cell Viability of PEDDSE

\section{CONCLUSION}

Aliphatic copolyesters were synthesized from PEG400, succinic acid, sebacic acid and 1, 12 - dodecanediol by a simple, safe and cost-effective melt poly condensation technique. The copolyester displays great dissolvability in familiar solvents which is an essential quality in perspective of its applications. The resulting structures of the repeating units were authorized on the basis of nuclear magnetic resonance spectrum. The thermal properties outlined by the differential scanning calorimetry and TGA analysis recorded that the $\mathrm{T}_{\mathrm{g}}$ and $\mathrm{T}_{\mathrm{m}}$ decreases with increasing number of methylene units. The thermal stability also confirms the decomposition temperatures were at $358.70^{\circ} \mathrm{C}$ and $401.16^{\circ} \mathrm{C}$, widely used in drug delivery applications. From the XRD studies, it is exquisite that PEDDSE is crystalline than PEDDSU. From GPC analysis, the molecular weights were identified for sebacate and succinate copolyester. The antitumor efficacy studies show that the PEDDSE copolyester is more anticarcinogenic than PEDDSU.

\section{ACKNOWLEDGEMENT}

The authors thank the Central Leather Research Institute (CLRI), Chennai and Indian Institute of Science (IISC), Bangalore for providing thermal analysis and GPC studies.

\section{REFERENCES}

1. S. Soulis, D. Triantou, S. Weidner, J. Falkenhagen and J. Simitzis, Polymer Degradation and Stability, 97, 2091 (2012), DOI:10.1016/j.polymdegradstab.2012.09.002.

2. P. Rizzareli, G. Impallomeni and G. Montaudo, Biomacromolecules, 5, 433 (2004), DOI: 10.1021/bm034230s.

3. A. Lindstrom, A.C. Albertsson and M. Hakkarainen, Polym Degrad Stab, 83, 487 (2004), DOI: 10.1016/j.polymdegradstab.2003.07.001.

4. S. S. Umare, A.S. Chandure and R.A. Pandey, Polymer Degradation and Stability, 92, 464 (2007), DOI:10.1016/j.polymdegradstab.2006.10.007 4.

5. S. M. Nikolic, D. Poleti and J. Djonlagic, European Polymer Journal, 39, 2183 (2003), DOI:10.1016/S0014-3057 (03)00139-3.

6. F. Xiong, J. Li, H. Wang, Y. Chen, J. Cheng and J. Zhu, Polymer, 47, 6636 (2006), DOI:10.1016/j.polymer.2006.07.020.

7. Z. H. Kang and C. L. Wang, Advanced Materials Research, 750, 1313 (2013), DOI: 10.4028.

8. J. M. Harris, Poly (Ethylene Glycol) Chemistry: Biotechnical and Biomedical Applications, Plenum Publishing, New York, 1992

9. A.S. Chandure, European Polymer Journal, 44, 2068 (2008), DOI: 10.1016/j.eurpolymj.2008.01.001.

10. Q. Liu, L. Jiang, R. Shi and L. Zhang, Progress in Polymer Science, 37, 715 (2012), DOI: 10.1021/bm0343242. 
11. S. Johnna, A. T. Kyriacos, Athanasiou, G. Richard, L. Antonios and G. Mikos, Journal of Biomedical Materials Research, 59, 429 (2002), DOI:10.1002/jbm.1259.

12. V. G. Kadajji and V. G. Betageri, Polymers, 3, 1972 (2011), DOI: 10.3390/polym3041972.

13. H. M. Ziboon, A. A. Saleh and S. H. Al-Lami, International Journal of Advanced Research, 2, 159 (2014).

14. T. Mosmann, J. Immunol.Methods, 65, 55 (1983).

15. L. Sowbagyalakshmi Prabha, R. Nanthini and G. Krishnaveni, Journal of Chemical and Pharmaceutical Research, 4, 2442 (2012).

16. J. Gowsika and R. Nanthini, Journal of Chemistry, 2014, 1 (2014), DOI:10.1155/2014/173814.

17. W. Dong, J. Ren, L. Lin, D. Shi, Z. Ni and M. Chen, Polymer Degradation and Stability, 97, 578 (2012), DOI:10.1016/j.polymdegradstab.2012.01.008.

18. P. S. Achary, The Journal of Adhesion, 78, 695 (2002), DOI:10.1080/00218460213492.

19. J. Ling, W. Chen and Z. Shen, Journal of Polymer Science, 43, 1787 (2005), DOI:10.1002/pola.20648.

20. A. S. Chandure, International Journal of Polymeric Materials, 56, 339 (2007), DOI: 10.1080/00914030600865093.

21. L. Sowbagyalakshmi Prabha, R. Nanthini and K. Prabhu, Oriental Journal of Chemistry, 28, 1659 (2012), DOI:10.13005/ojc/280416.

22. U. C. Mashelkar, J. B. Patil, R. S. Kenny and N. R. Chindarkar, Rasayan. J. Chem., 8, 422 (2015).

23. M. Mazurek, T. Bruliński, K. Tomczyk, P. Parzuchowski, Z. Florjańczyk, A. Plichta and G. Rokicki, Journal of Polymer Research, 34, 1 (2015), DOI: 10.1007/s10965-015-0655-0.

24. O. Ahmed and H. El-Nezhawy. Archiv der Pharmazie, 344, 631 (2011), DOI:10.1002/ardp.201000367.

25. T. Kamalanathan and R. Nanthini, Universal Journal of Pharmacy, 02, 102 (2013).

26. M. Soccia, N. Lotti, M. Gazzano, M. Govoni, E. Giordano and A. Munari, Reactive and Functional Polymers, 72, 856 (2012), DOI:10.1016/j.reactfunctpolym.2012.08.002.

27. V. Karavelidis, D. Giliopoulos, E. Karavas and D. Bikiaris, European Journal of Pharmaceutical Sciences, 41, 636 (2010), DOI:10.1016/j.ejps.2010.09.004.

28. P. Rizzarelli, C. Puglisi and G. Montaudo, Polymer Degradation and Stability, 85, 855 (2004), DOI:10.1016/j.polymdegradstab.2004.03.022.

29. A. Ravi, R. Nanthini, M. Karunanidhi and V. Jaishankar, Oriental Journal of Chemistry, 26, 547 (2010).

30. S. Papadimitriou, D. Bikiaris, Journal of Controlled Release, 138, 177 (2009), DOI:10.1016/j.jconrel.2009.05.013.

31. Y. Chen, Y. Yang, J. Su, L. Tan and Y. Wang, Reactive and Functional Polymers, 67, 396 (2007), DOI: $10.1016 / \mathrm{j}$.

32. F. T. Tan, G. D. Cooper, M. Maric and A. J. Nicell, Polymer Degradation and Stability, 93, 1479 (2008), DOI:10.1016/j.polymdegradstab.2008.05.005.

33. R. B. Badisa, O. Tzakou, M. Couladis and E. Pilarinou, Pharmaceutical Biology, 42, 640 (2005), DOI: $10.1080 / 13880200490902590$.

34. J. Kaban, J. Reveny, J. Tarigan and N.F. Zebua, Rasayan. J. Chem., 11(1), 294 (2018).

35. V. N. Ariharan and P. N. Prasad, Rasayan. J. Chem., 7, 260 (2014).

[RJC-1992/2017] 